\title{
INTERNAL FACTORS OF BUSINESS AND INTERNAL INDIVIDUAL AFFECTING ENTREPRENEURIAL ACTIVITY AND BUSINESS GROWTH OF BROILER CHICKENS IN PROVINCE
}

\section{FAKTOR INTERNAL USAHA DAN INTERNAL INDIVIDU YANG MEMPENGARUHI AKTIVITAS KEWIRAUSAHAAN DAN PERTUMBUHAN USAHA AYAM BROILER DI PROVINSI JAMBI}

\author{
Rufti Puji Astuti \\ Dosen pada Program Studi Agribisnis, Universitas Bangka Belitung \\ Email: ruftipuji24@gmail.com
}

\begin{abstract}
The purpose of the study in general is to determine the factors that affect the growth of broiler business in the eastern zone of Jambi Province. These factors are focused on internal factors, namely the internal factors of individuals and internal factors of business. The objectives of the research are 1) to identify the internal factors of the individual that influence the growth of the business 2) to identify the internal factors of the individual business affecting the growth of the business and 3) to analyze the influence of internal factors of internal factors and internal factors on business growth. The research was conducted by survey method. Analysis and Data Processing using Stuctural Equation Modeling (SEM) and Smart Patial Least Square (Smart-PLS 2.0). The results showed that innovation, risk taking, and production power are internal factors of individual and internal business that affect business growth. Both factors are known to be significant and positively affect business growth. This study also found that business growth is influenced by internal factors of individual and internal business indirectly, that is through a series of entrepreneurial activities undertaken by farmers. Both have a positive relationship, meaning that the diversity of the growth of broiler farming business in Jambi Province occurs because of the encouragement of entrepreneurship activities of farmers, driven by internal factors of individuals and internal factors of business.
\end{abstract}

Keywords: Internal Factors, Entrepreneurial Activity, Business Growth

\begin{abstract}
ABSTRAK
Tujuan penelitian secara umum adalah untuk mengetahui faktor-faktor yang mempengaruhi pertumbuhan usaha ayam broiler dizona timur Provinsi Jambi. Faktor-faktor yang dimaksud difokuskan pada faktor internal, yaitu faktor internal individu dan faktor internal usaha. Tujuan penelitian yang disusun adalah untuk 1) Mengidentifikasi faktor internal individu yang mempengaruhi pertumbuhan usaha 2)Mengidentifikasi faktor internal usaha individu yang mempengaruhi pertumbuhan usaha dan 3)Menganalisis pengaruh faktor faktor internal individu dan faktor internal usaha terhadap pertumbuhan usaha. Penelitian dilakukan dengan metode survey. Analisis dan Pengolahan data menggunakan Stuctural Equation Modelling (SEM) dan Smart Patial Least Square (Smart-PLS 2.0). Hasil penelitian menunjukan bahwa inovasi, pengambilan risiko, dan daya produksi merupakan faktor internal individu dan internal usaha yang mempengaruhi pertumbuhan usaha. Kedua faktor diketahui signifikan dan positif mempengaruhi pertumbuhan usaha. Penelitian ini juga menemukan bahwa pertumbuhan usaha dipengaruhi oleh faktor internal individu dan internal usaha secara tidak langsung, yaitu melalui serangkaian aktivitas kewirausahaan yang dilakukan peternak.Keduanya memiliki hubungan positif, artinya keragaman pertumbuhan usaha peternakan ayam broiler di zona timur Provinsi Jambi terjadi karena adanya dorongan dari aktivitas kewirausahaan peternak, yang digerakan oleh faktor internal individu dan faktor internal usaha.
\end{abstract}

Kata kunci: Faktor Internal, Aktivitas Kewirausahaan, Pertumbuhan Usaha

\section{A. PENDAHULUAN}

Masalah kewirausahaan saat ini memiliki peran yang semakin penting dalam menentukan keberhasilan program-program pembangunan. Indikator keberhasilan program pembangunan saat ini tidak cukup dijelaskan oleh adanya pertumbuhan tingkat ekonomi saja, namun juga dibutuhkan dibutuhkan kreatifitas dan inovasi untuk menjaga stabilitas perekonomiaannya. Banyak peneliti saat ini menaruh perhatian besar pada peran kewirausahaan dalam pembangunan. Alasannya kreativitas dan inovasi yang merupakan elemen kunci dari kewirausahaan, dinilai mampu memberikan pengaruh pada pendapatan masyarakat. Dalam konteks tersebut 


\section{Rufti Puji Astuti}

kewirausahaan ditempatkan sebagai penggerak pertumbuhan ekonomi.

Partisipasi seorang wirausaha dalam pelaksanaan program pembangunan sangat dibutuhkan. Adanya peran seorang wirausahawan juga dinilai mampu menciptakan akselerasi pembangunan. Kemampuan tersebut ditentukan melalui pembukaan jenis usaha baru, penyerapan tenaga kerja dan pembukaan lapangan kerja, serta peningkatan output perkapita nasional. Artinya wirausaha memiliki peran strategis dalam mendukung program pembangunan secara nasional. Instansi pendidikan dan para pembuat kebijakan di Indonesia, saat ini juga telah menaruh perhatian besar pada masalah kewirausahaan. Alasannya seorang wirausaha mampu mengembangkan ide usaha baru ,dan merubahnya menjadi suatu yang menguntungkan.

Masalah kewirausahaan merupakan persoalan paling penting dalam pembangunan ekonomi. Indikator perkembangan kewirausahaan dapat dipelajari dari jumlah wirausaha yang dimiliki. Ilmuwan dari Amerika Serikat (AS) David McClelland menyatakan bahwa, suatu Negara dapat dikatakan maju apabila jumlah wirausaha yang dimiliki minimal sebanyak $2 \%$ dari jumlah populasi penduduknya. Menurut Naude (2008), untuk mengetahui jumlah wirausaha di suatu Negara dapat dilakukan dengan mengukur tingkat aktivitas kewirausahaan. Naude (2008) mendifinisikan aktivitas kewirausahaan sebagai tindakantindakan seorang wirausaha dalam mengelola usahanya.

Subsektor peternakan ayam broiler di Indonesia, merupakan salah satu subsektor peternakan yang berkembang pesat. Jika dibandingkan dengan subsektor peternakan lainnya, subsector peternakan ayam broiler memiliki pertumbuhan bisnis yang lebih cepat. Perkembangan subsector ini, didukung oleh potensi bisnis dan adanya keragaman inovasi, baik inovasi teknologi pakan maupun teknologi genetic. Inovasi pada peternakan ayam broiler, menunjukan bahwa dalam pengelolaan usaha peternakan ayam broiler terdapat berbagai aktivitas kewirausahaan. Perkembangan inovasi juga telah menyelamatkan dari keterpurukan yang dialami akibat serangan wabah flu burung. Kondisi yang demikian,menjadi alasan mengapa pertumbuhan populasi ternak ayam broiler lebih tinggi diantara subsector peternakan lainnya. Menurut Burhanuddin et al. (2013), sector ini juga layak mendapat dukungan kebijakan dari pemerintah. Alasannya melalui berbagai aktivitas kewirausahaan yang dimiliki, subsector peternakan ayam broiler secara nyata telah mampu berkontribusi positif dalam menambah pasokan wirausahabaru di Indonesia.
Perkembangan yang pesat pada bisnis peternakan ayam broiler juga terjadi di Provinsi Jambi. Usaha peternakan ayam broiler di Provinsi Jambi saat ini, telah didominasi oleh usaha kemitraan (85\%), (Poultry Indonesia 2015). Pertumbuhan bisnis ini juga terlihat dari jumlah populasi ayam broiler yang terus mengalami peningkatan, seperti terlihat pada Tabel 1. Tidak hanya itu, Kehadiran berbagai perusahaan peternakan dan tiga perusahaan pembibitan di Provinsi Jambi, juga menunjukan bahwa usaha peternakan ayam broiler memiliki potensi untuk terus berkembang pesat.

Tabel 1 Data populasi ternak ayam broiler Provinsi Jambi

\begin{tabular}{lllll}
\hline \multirow{2}{*}{ Zona } & Kabupaten & \multicolumn{3}{c}{ Tahun } \\
\cline { 3 - 5 } & & 2012 & 2013 & 2014 \\
\hline Tengah & BatangHari & 4.185 .000 & 4.285 .440 & 4.713 .984 \\
Barat & Bungo & 1.171 .800 & 2.870 .072 & 3.157 .079 \\
Timur & Muaro & 164889 & 824707 & 907178 \\
\hline
\end{tabular}

Sumber: Dinas Peternakan Provinsi Jambi, 2014

Angka pertumbuhan populasi pada ketiga wilayah tidak merata. Data pada Tabel 1 menunjukan bahwa usaha di zona timur memiliki tingkat pertumbuhan yang lebih beragam. Jumlah populasi ternak ayam broiler di zona timur lebih kecil, namun jika melihat tingkat pertumbuhan populasinya, usaha di zona timur memiliki angka pertumbuhan populasi tertinggi (13\%) pada tahun 2014. Pertumbuhan usaha peternakan ayam broiler ini dicerminkan oleh peningkatan skala pemeliharaan, atau jumlah populasi ternak yang dipelihara. Artinya tingkat pertumbuhan populasi ternak ayam broiler pada Tabel 1, juga dapat dipahami sebagai pedoman pertumbuhan usaha. Pertanyaan selanjutnya apa faktor yang mempengaruhi pertumbuhan usaha ayam broiler di zona timur?

Pertumbuhan usaha merupakan salah satu dampak dari proses kewirausahaan, maka untuk mengetahui faktor pertumbuhan usaha, dapat dilakukan dengan menilai kondisi kewirausahaanya. Oleh karena itu perlu dilakukan kajian yang mengukur aktivitas kewirausahaan peterenakan ayam broiler di Provinsi Jambi, dan faktor internal individu dan faktor internal usaha yang mempengaruhinya.Oleh karena itu diperlukan analisis faktor-faktor yang mempengaruhi pertumbuhan usaha secara menyeluruh, melalui pendekatan kewirausahaan. Berdasarkan latar belakang dan identifikasi masalah yang telah diuraikan tersebut, maka perumusan masalah dari penelitian ini diantaranya:

1. Apakah inovasi dan kemampuan pengambilan resiko merupakan faktor internal individu yang mempengaruhi 
aktivitas kewirausahaan peternak dan pertumbuhan usaha ayam broiler

2. Apakah daya saing usaha, daya produksi, merupakan faktor internal usaha yang mempengaruhi aktivitas kewirausahaan dan pertumbuhanusaha ayam broiler

3. Apakah aktivitas kewirausahaan mempengaruhi pertumbuhan usaha ayam broiler.

\section{B. METODE PENELITIAN}

Penelitian dilakukan di zona timur provinsi jambi, tepatnya di kabupaten Muaro Jambi dan kota Jambi. Sampel responden yang digunakan dalam penelitian ini adalah peternakan ayam broiler kemitraan plasma dari PT. Indah Ternak Mandiri yang masih beroprasi. Penentuan jumlah responden dilakukan berdasarkan metode simple random sampling, sebanyak 60 peternak. Pengambilan data melalui wawancara dilakukan dalam bentuk wawancara langsung kepada peternak plasma, pekerja kandang dan informan kunci (Tehnical Servis) masing-masing plasma dan pengurus desa setempat, untuk mendapatkan keakuratan data. Data yang telah diperoleh selanjutnya akan diolah dan dianalisis dengan metode analisis diskriptif kualitatif maupun kuantitatif. Data kuantitatif diolah dengan bantuan program Microsoft Exel 2010,dan dianalisis dengan analisis Structural Equation Modelling (SEM) menggunakan smart Partial Least Squares (PLS). SEM dengan PLS dapat digunakan digunakan untuk memprediksi variable laten endogenous atau mengidentifikasi variabel-variabel utama jika riset merupakan riset eksploratori atau perluasan suatu teori struktural yang ada. SEM-PLS merupakan metode analisis yang powerful, dapat diterapkan pada semua skala data, tidak membutuhkan banyak asumsi dan ukuran sampel tidak harus besar.

\section{HASIL DAN PEMBAHASAN}

Hasil analisis SEM-PLS terhadap model menunjukkan bahwa aktivitas kewirausahaan peternak ayam broiler di provinsi Jambi dipengaruhi oleh faktor internal, baik faktor internal individu peternak maupun faktor internal usaha. Faktor internal individu dijelaskan oleh laten inovasi (IN) dan laten pengambilan resiko (PRS). Faktor internal usaha dijelaskan oleh laten daya produksi (DYP).

Variabel laten inovasi, pengambilan resiko dan daya produksimemiliki nilai t-value lebih besar dari 1.96, sehingga ketiga vareiabel secara langsung dan positif mempengaruhi aktivitas kewirausahaan peternak.

Tabel 2.Koefisien parameter jalur faktor internal individu dan usaha

terhadap aktivitas kewirausahaan

\begin{tabular}{lccc}
\hline Hipotesis & & $\begin{array}{l}\text { Original } \\
\text { Sample }\end{array}$ & t-value \\
\hline $\begin{array}{l}\text { Inovasi } \\
\text { Kewirausahaan }\end{array}$ & Aktivitas & 0,581 & $6,053^{*}$ \\
$\begin{array}{l}\text { Pengambilan Resiko } \\
\text { Kewirausahaan }\end{array}$ & Aktivitas & 0,582 & $8,072^{*}$ \\
$\begin{array}{l}\text { Daya Saing -> } \\
\text { Kewirausahaan }\end{array}$ & Aktivitas & $-0,013$ & 0,166 \\
$\begin{array}{l}\text { Daya Produksi-> } \\
\text { Kewirausahaan }\end{array}$ & Aktivitas & 0,183 & $1,969^{*}$ \\
\hline *t(0.05): 1.96 & & \\
\hline
\end{tabular}

Faktor internal individu cenderung lebih besar mempengaruhi aktivitas kewirausahaan peternak ayam broiler. Hal ini karena, variabel inovasi dan pengambilan resiko memiliki nilai koefisien parameter jalur $(\gamma=0,581$ dan $\gamma=0,582)$ lebih besar dari nilai koefisien parameter jalur variabel daya produksi $(\gamma=$ $0,183)$. Artinya aktivitas-aktivitas kewirausahaan peternak lebih banyak dibentuk dari berbagai aktivitas inovasi dan tingkat keberanian pengambilan resiko yang beragam. Hal ini sesuai dengan hasil penelitian (Burhanuddin 2014) yang menyatakan bahwa variabel inovasi, keberanian pengambilan resiko dan daya produksi usaha merupakan variabel yang mempengaruhi aktivitas kewirausahaan peternak. Selanjutnya variabel inovasi dan pengambilan resiko dikelompokkan sebagai faktor internal individu,dan variabel daya produksi sebagai faktor internal usaha, yang keduanya mempengaruhi aktivitas kewirausahaan. analisis selengkapnya terhadap masing-masing faktor internal individu dan usaha adalah sebagai berikut:

\section{Faktor Internal Individu}

Faktor internal individu yang dimaksud adalah faktor kewirausahaan yang berasal dari diri seorang peternak untuk melakukan aktivitasaktivitas kewirausahaan.Peternak merupakan seorang wirausaha yang melakukan perencanaan, dan membuat keputusan pada usaha yang dikelolanya. Hal ini menegaskan bahwa faktor internal individu memiliki peran penting dalam membentuk aktivitas kewirausahaan.

a. Inovasi

Keberadaan inovasi pada usaha peternakan ayam broiler memiliki peranan penting, yaitu sebagai faktor yang paling kuat mempengaruhi aktivitas kewirausahaan peternak. hal ini sesuai dengan pendapat burhanuddin et.al (2013)yang menyatakan bahwa sebesar 83 persen aktivitas kewirausahaan peternak ayam broiler dibentuk dari inovasi.Aktivitas inovasi dapat dijelaskan melalui kegiatan memperbaiki cara-cara yang ada, maupun menemukan hal-hal baru dalam rangka meningkatkan nilai tambah. Artinya peternak adalah seorang wirausaha yang mengimplementasikan hasil temuan untuk memperbaiki cara-cara produksi yang telah ada, 


\section{Rufti Puji Astuti}

atau menemukan produk baru dengan cara lama. Hal ini sesuai dengan pernyataan Joseph Schumpeter dalam Casson et.al. (2006), bahwa Wirausaha adalah orang yang akan mengimplementasikan hasil temuan dengan merubah cara-cara produksi, mengolah produk lama dengan teknologi yang belum dicobakan pada produk tersebut, atau mengolah produk produk baru dengan teknologi lama.

Aktivitas inovasi pada usaha petrenakan ayam broiler terdapat pada kegiatan budidaya maupun pemasaran. Aktivitas-aktivitas inovasi yang dilakukan peternak ayam broiler dapat dilihat dari intensitas inovasi yang dilakukan peternak, kesediaan berinovasi, tingkat penggunaan teknologi, aktivitas pengenalan produk baru, penggunaan metode produksi baru, dan pembukaan pasar baru.Aktivitas inovasi memiliki pengaruh langsung dan signifikan terhadap aktivitas kewirausahaan, seperti terlihat pada tabel 3. Hal ini karena laten inovasi memiliki nilai t-value lebih besar dari 1.96. Nilai t-value yang dimiliki laten inovasi adalah 6.053. Hasil analisis PLS juga menunjukan bahw, aktivitas inovasi yang dilakukan peternak ayam broiler kemitraan di Provinsi Jambi, cenderung lebih kuat dibentuk oleh indikator penggunaan metode berproduksi baru ( $\lambda=0.959$ dan T-value 105.532).

Tabel 3 Kontribusi indikator inovasi berdasarkan nilai loding faktor dan t-value

\begin{tabular}{llcc}
\hline $\begin{array}{l}\text { Variabel } \\
\text { Laten }\end{array}$ & Variabel Manifest & $\begin{array}{c}\text { Loading } \\
\text { factor }\end{array}$ & t-value \\
\hline & Intensitas Inovasi & 0.894 & 38.391 \\
& Kesediaan Berinovasi & 0.939 & 71.138 \\
Inovasi & Tingkat Teknologi & 0.923 & 56.304 \\
(INV) & Pengenalan Produk Baru & 0.937 & 83.425 \\
& Penggunaan Metode & 0.959 & 105.53 \\
& Berproduksi Baru & 0.930 & 68.839 \\
\hline
\end{tabular}

Aktivitas inovasi peternak melalui aktivitas penggunaan metode berproduksi baru, dapat dilihat dari aktivitas penggunaan metode baru dalam berproduksi. Hal ini menunjukan bahwa, inovasi peternak dibentuk oleh aktivitas melakukan perubahan pada hal yang lebih baik. Aktivitas perubahan padahal yang lebih baik, dapat dilihat dari aktivitas peternak beralih pada jenis DOC yang digunakan. Menurut peternakjenis DOC yang saat ini digunakan lebih baik, jika dibandingkan awal memulai usaha. Peternak saat ini telah beralih menggunakan DOC yang sudah divaksin. Perubahan pada jenis DOC yang digunakan, dilatarbelakngi oleh upaya peternak untuk mengendalikan biaya. Peternak menyakini bahwa DOC yang sudah divaksin memiliki daya tahan tubuh yang lebih baik, yaitu dijelaskan oleh tingkat kematian yang lebih rendah. Penggunaan DOC vaksin memberikan beberapa keuntungan, salah satunya peternak terhindar dari kerugian yang disebabkan oleh kesalahan dalam proses vaksinasi. Peternak menyatakan bahwa dengan tingkat kematian yang semakin rendah, dan adanya penghematan dari biaya vaksinasi, kinerja usaha peternakan yang dikelola semakin baik.

Aktivitas kewirausahaan pada usaha peternakan ayam broiler akan meningkat, seiring kinerja usaha yang semakin baik. Menurut Burhanuddin (2014), perubahan pada kinerja usaha peternakan ayam broiler ke arah yang positif, akan meningkatkan aktivitas kewirausahaan peternak. Dalam konteks ini dijelaskan bahwa, dengan kinerja usaha yang semakin baik peternak dapat mengembangkan usahanya. Sehingga aktivitas kewirausahaan peternak akan meningkat, seiring aktivitasaktivitas yang dilakukan peternak dalam mengembangkan usahanya.

Aktivitas inovasi pada usaha peternakan ayam broiler kemitraan di Provinsi Jambi, dilihat dari sudut pandang adopternya, yaitu peternak. Berdasarkan pemahaman tersebut, aktivitas melakukan hal-hal baru yang lebih baik, dapat diartikan sebagai aktivitas peternak menerapkan hasil temuan lama maupun baru yang sebelumnya tidak diketahui. Sehingga hasil temuan tersebut menjadi baru bagi peternak. Dengan kata lain, aktivitas melakukan hal-hal baru yang lebih baik adalah melakukan aktivitas diluar kebiasaannya, yang dapat memberikan hasil lebih baik pada usahanya. Penggunaan metode berproduksi baru, juga dapat dilihat dari aktivitas peternak yang melakukan penimbangan dan pemeriksaan kesehatan ternak secara teratur. Tidak hanya itu, penggunaan metode berproduksi baru juga dilakukan dengan mengatur waktu dan cara pemberian pakan, serta kegiatan sanitasi secara serentak.

\section{b. Pengambilan Resiko}

Wirausaha adalah orang yang berani menanggung resiko dalam mendirikan usaha, untuk memperoleh keuntungan. Wirausaha berada di lingkungan yang tidak pasti.Wirausaha adalah orang yang berupanya meningkatkan nilai jual suatu produk atau jasa, dengan mengkombinasikan berbagai peluang dan sumber daya yang tersedia di lingkungan (Joseph Schumpeter dalam Casson et.al. 2006). Peternakan ayam brioler merupakan salah satu usaha yang banyak mengandung resiko. Sehingga peternak dapat dikatakan sebagai wirausaha, karena menghadapi resiko kerugian dalam usahanya. Resiko merupakan salah satu faktor yang mempengaruhi aktivitas kewirausahaan pada peternakan ayam broiler (Burhanuddin 2014). Resiko merupakan salah satu faktor internal individu yang kuat mempengaruhi aktivitas kewirausahaan peternak. 
Hasil analisis menunjukan bahwa pengambilan resiko memiliki nilai t-value lebih besar dari 1.96, yaitu 8.072. Artinya laten pengambilan resiko memiliki pengaruh langsung dan signifikan terhadap aktivitas kewirausahaan. Peternak memiliki keberanian menganggung resiko dalam pekerjaan, dalam keungan, resiko dalam produksi, dan risiko berinvestasi. Keberanian peternak dalam menanggung resiko, cenderung lebih kuat direfleksikan oleh kontribusi indikator mengambil resiko pekerjaan.

Tabel 4 Indikator resiko berdasarkan nilai loding faktor dan t-

\begin{tabular}{|c|c|c|c|}
\hline $\begin{array}{l}\text { Variabel } \\
\text { Laten }\end{array}$ & Variabel Manifest & $\begin{array}{c}\text { Loading } \\
\text { factor }\end{array}$ & t-value \\
\hline \multirow{4}{*}{$\begin{array}{l}\text { Resiko } \\
\text { (PRS) }\end{array}$} & Resiko dalam pekerjaan & 0.970 & 169.263 \\
\hline & Resiko dalam keuangan & 0.964 & 138.106 \\
\hline & Resiko dalam produksi & 0.964 & 126.663 \\
\hline & Resiko dalam berinvestasi & 0.920 & 57.770 \\
\hline
\end{tabular}

Keberanian mengambil resiko pada pekerjaan, merupakan indikator yang paling kuat merefleksikan variabel pengambilan resiko. Hal ini karena, indikator mengambil resiko pekerjaan memiliki nilai faktor loading paling besar, yaitu $(\lambda=0.970$ dan $t$-value 169.263). Kehilangan waktu berkumpul keluarga dan waktu istrirahat, merupakan resiko yang paling besar dihadapi peternak ayam broiler kemitraan di Provinsi Jambi. Jumlah waktu berkumpul keluarga berkurang disebabkan oleh lokasi kandang yang jauh dari tempat tinggal peternak. pekerjaan sebagai peternak ayam broiler juga menyebabkan peternak sering menghadapi protes warga, terutama disebabkan masalah bau dan lalat. Namun demikian peternak hingga saat ini dapat bertahan dan mengelola usahanya, dengan upaya mengendalikan resiko yang ada. Peternak telah melakukan upaya mengurangi pencemaran bau dan lalat. Tidak hanya itu peternak juga melibatkan warga sekitar lokasi kandang, sebagai tenaga kandang maupun sebagai tenaga panen.

\section{Faktor Internal Usaha}

Faktor internal usaha yang dimaksud adalah faktor yang berasal dari kondisi internal usaha peternakan ayam broiler. Faktor internal usaha merupakan salah satu faktor yang mempengaruhi tingkat aktivitas kewirausahaan peternak ayam broiler. Faktor internal usaha yang mempengaruhi aktivitas kewirausahaan, salah satunya adalah daya produksi.

\section{a. Daya Produksi}

Daya produksi merupakan keseluruhan proses mengkombinasikan berbagai input untuk menghasilkan output. Daya produksi dalam peternakan ayam broiler adalah keseluruhan proses mengkombinasikan input-input (DOC, pakan, vaksin, kandang,peralatan), untuk menghasilkan output berupa ayam hidup, serta hasil ikutanya.
Tabel 5 Kontribusi Indikator daya produksi berdasarkan nilai faktor loding dan tvalue

\begin{tabular}{llcc}
\hline $\begin{array}{l}\text { Variabel } \\
\text { Laten }\end{array}$ & Variabel Manifest & $\begin{array}{c}\text { Loading } \\
\text { factor }\end{array}$ & t-value \\
\hline & Diversifikasi prodiksi & 0.941 & 46.195 \\
& Mengantisipasi & 0.919 & 60.223 \\
Daya & kebutuhan pasar & 0.913 & 44.139 \\
Produksi & Menawarkan kualitas & 0.574 & 14.551 \\
(DYP) & Mengendalikan biaya & 0.867 & 24.254 \\
& Produktivitas & 0.940 & 87.422 \\
\hline
\end{tabular}

Hasil analisis PLS menunjukan bahwa daya produksi memiliki pengaruh langsung dan signifikan terhadap aktivitas kewirausahaan. Hal ini karena, laten daya produksi memiliki nilai tvalue lebih besar dari 1.96, besar nilai t-value laten daya produksi adalah 1.97. Daya produksi usaha peternakan ayam broiler kemitraan di provinsi jambi, cenderung lebih besar direfleksikan oleh kontribusi indikator diversifikasi produksi. Hal ini karena, indikator diversifikasi produksi memiliki nilai faktor loading paling besar $(\lambda=0.941)$. Nilai faktor loading masing-masing indikator yang merefleksikan daya produksi peternakan ayam broiler kemitraan di provinsi jambi, dapat dilihat pada Tabel 5.

Diversifikasi produksi merupakan keragaman proses produksi yang dilakukan peternak untuk meningkatkan daya produksi usaha. Peternak selalu melakukan penjadwalan panen, dan menerapkan teknologi produksi yang berbeda saat periode untung dan rugi. Penerapan teknologi produksi berbeda pada periode untung dan rugi, diupayakan untuk memperoleh kombinasi input yang dapat memberi keuntungan lebih baik. Aktivitas penjadwalan panen diupayakan peternak untuk menghindari penundaan waktu panen. Menurut peternak, penundaan waktu panen dapat menyebabkan biaya produksi semakin meningkat. Dalam konteks ini diketahui bahwa, penundaan waktu panen menyebabkan jumlah pakan yang digunakan untuk menghasilkan bobot $1 \mathrm{~kg}$ semakin bertambah.

Burhanuddin (2014) juga menyatakan bahwa faktor lain yang mempengaruhi daya produksi usaha adalah ketepatan waktu panen. Penundaan waktu panen juga merupakan sumber kerugian pada usaha, karena penerimaan berpotensi turun, yang disebabkan oleh tambahan biaya pakan. Efisiensi produksi menurut Burhanuddin (2014), merupakan salah satu syarat penting untuk meraih keuntungan dan upaya meningkatkan aktivitas kewirausahaan. $\mathrm{Hal}$ ini mengindikasikan bahwa upaya meningkatkan aktivitas kewirausahaan peternak 


\section{Rufti Puji Astuti}

ayam broiler kemitraan di Provinsi Jambi, dapat dilakukan dengan meningkatkan daya produksi usahanya, yaitu melalui penerapan diversifikasi produksi.

\section{Pengaruh Aktivitas Kewirausahaan} terhadap Pertumbuhan Usaha Peternakan Ayam Broiler

Pertumbuhan usaha peternakan ayam broiler kemitraan di Provinsi Jambi, cenderung kuat di refleksikan oleh indikator pertumbuhan skala usaha (PU1) dan pertumbuhan pendapatan usaha (PU2). Hal ini karena, kedua indikator memiliki nilai faktor loading cukup besar, yaitu pertumbuhan skala usaha $(\lambda=0.807)$ dan pertumbuhan pendapatan usaha $(\lambda=0.888)$. Indikator pertumbuhan usaha tersebut juga memiliki nilai t-value lebih besar dari 1.96. Nilai faktor loading dan t-value untuk indikator pertumbuhan usaha, secara lengkap dapat dilihat pada Tabel 6.

Tabel 6 Kontribusi indikator pertumbuhan usaha berdasarkan nilai loading faktor dan $\mathrm{t}$ - value

\begin{tabular}{llll}
\multicolumn{4}{c}{ nilai loading faktor dan t- value } \\
\hline $\begin{array}{l}\text { Variabel } \\
\text { Laten }\end{array}$ & Variabel Manifest & $\begin{array}{l}\text { Loading } \\
\text { Faktor }\end{array}$ & t-value \\
\hline & $\begin{array}{l}\text { Perubahan tingkat } \\
\text { skala usaha }\end{array}$ & 0.807 & 12.184 \\
$\begin{array}{l}\text { Pertumbuhan } \\
\text { Usaha }\end{array}$ & $\begin{array}{l}\text { Perubahan tingkat } \\
\text { pendapatan }\end{array}$ & 0.888 & 21.028 \\
& & & \\
\hline
\end{tabular}

Pertumbuhan tingkat pendapatan usaha peternakan ayam broiler kemitraan di Provinsi Jambi, dapat dilihat dari perbedaan tingkat pendapatan usaha saat pengambilan data dan tingkat pendapatan di awal usaha. Berdasarkan nilai faktor loading yang dimiliki, indikator pertumbuhan pendapatan merupakan indikator yang relatif paling kuat $(\lambda=0.888)$, berkontribusi merefleksikan pertumbuhan usaha. Artinya pertumbuhan usaha peternakan ayam broiler kemitraan di Provinsi Jambi, terjadi karena adanya dorongan dari pertumbuhan pendapatan usaha. Hal ini menunjukan bahwa, upaya pemerintah daerah Provinsi Jambi dalam meningkatkan pertumbuhan usaha peternakan ayam broiler, dapat dilakukan melalui berbagai program dan kebijakan yang dapat menghasilkan pertumbuhan pendapatan usaha.

Tabel 7 Ringkasan hasil keseluruhan koefisien parameter jalur

\begin{tabular}{lccc}
\hline Path & $\begin{array}{c}\text { Original } \\
\text { Sample }\end{array}$ & $\begin{array}{c}\text { t- } \\
\text { value }\end{array}$ & Kesimpulan \\
\hline $\begin{array}{l}\text { Aktivitas Kewirausahaan } \\
\rightarrow \text { Pertumbuhan usaha }\end{array}$ & 0.462 & 7.917 & signifikan \\
\hline
\end{tabular}

$\mathrm{t}(0.05): 1.96$
Pertumbuhan usaha dipengaruhi secara langsung olehAktivitas kewirausahaan peternak. Koefisien parameter jalur laten eksogen aktivitas kewirausahaan dan laten endogen pertumbuhan usaha adalah ( $\beta=0.462)$, dan nilai t-value (7.917 ) lebih besar dari 1.96. Laten eksogen aktivitas kewirausahaan dan laten endogen pertumbuhan usaha, memiliki korelasi positif. Artinya aktivitas kewirausahaan memiliki pengaruh yang cukup kuat terhadap pertumbuhan usaha. Dengan kata lain, aktivitas kewirausahaan merupakan modal peternak untuk memperoleh pertumbuhan pendapatan. Peternak menyakini bahwa dengan melakukan perubahan, mengambil resiko,dan meningkatkan daya produksi usaha, dapat memperoleh pertumbuhan pendapatan. Menurut peternak, pertumbuhan pendapatan yang diperoleh, disebabkan oleh adanya penurunan biaya, produksi dan penerimaan yang semakin meningkat. Hubungan korelasi positif pada aktivitas kewirausahaan dan pertumbuhan usaha, mengindikasikan bahwa upaya meningkatkan pertumbuhan usaha peternakan ayam broiler dapat dilakukan dengan cara meningkatkan aktivitas kewirausahaan peternak ayam broiler kemitraan. Hal ini karena, korelasi positif antara aktivitas kewirausahaan dan pertumbuhan usaha menunjukan bahwa semakin tinggi tingkat aktivitas kewirausahaan, semakin tinggi pula pertumbuhan usaha.Hasil penelitian ini sesuai dengan hasil penelitian sebelumnya yang menyatakan bawa, pertumbuhan tingkat pedapatan merupakan salah satu indikator mempengaruhi pentumbuhan usaha Burhanuddin (2014). Peran Wirausaha dalam menciptakan pertumbuhan usaha, menurut Ferrante (2005) dalam Burhanuddin (2014) adalah memalui kemampuan yang dimiliki untuk memberikan lebih banyak waktu pada aktivitas-aktivitas yang lebih produktif.

\section{KESIMPULAN}

Inovasi dan pengambilan risiko, dan daya produksi merupakan faktor internal individu dan faktor internal usaha yang mempengaruhi pertumbuhan usaha. Kedua faktor diketahui signifikan dan positif mempengaruhi pertumbuhan usaha secara tidak langsung, yaitu melalui serangkaian aktivitas kewirausahaan yang dilakukan peternak. Keduanya memiliki hubungan positif, artinya keragaman pertumbuhan usaha peternakan ayam broiler di Provinsi Jambi terjadi karena adanya dorongan dari aktivitas kewirausahaan peternak, yang digerakkan oleh faktor internal individu dan faktor internal usaha.

\section{DAFTAR PUSTAKA}

1. Anonim. 2015. Menelisik Perunggasan Jambi. Poultry Indodesia.[Diakses Pada 16 
April 2015]. [Tersedia Pada:www. Poultry indonesia.com].

2. BadanPusatStatistik Provinsi Jambi. 2014. Jambi Dalam Angka 2014. Jambi.

3. Burhanuddin, Harianto,NurmalinaR.\&PambudyR. 2013.The Determining Factors Of Entrepreneurial Activity In Broiler Farms.Journal.ipb mediapeternakan.36(3):230-236.

4. Burhanuddin.2014.

PengaruhAktivitasKewirausahaanPeternakA yam BroilerTerhadapPertumbuhanBisnis Peternakan di Indonesia.[Disertasi]: SekolahPascaSarjanaInstitutPertanian Bogor.
5. Casson M. Yeung B. Basu A. Wadeson N.2006. The Oxford Handbook Of Entrepreneurship. New York (Us): Oxford University Press Inc.

6. Naude W. 2008. Entrepreneurship In Economic Development. Journal of Economic Literature. (20):1-45. 